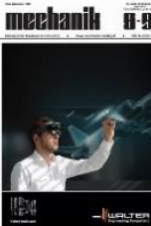

Authors: Jan Burek, Rafał Flejszar

Title of article: „Analiza warstwy skrawanej w obróbce elementów cienkościennych o złożonej geometrii” („Analysis of the machined layer of thin-walled complex geometry parts")

Mechanik, Vol. 91, No. 8-9 (2018): pages 778-780

DOI: https://doi.org/10.17814/mechanik.2018.8-9.132

\title{
Analysis of the machined layer of thin-walled complex geometry parts
}

\author{
Analiza warstwy skrawanej \\ w obróbce elementów cienkościennych o złożonej geometrii
}

\author{
JAN BUREK \\ RAFAt FLEJSZAR *
}

Presented is the method of analysis of a machined layer in a CAD system in milling process, and described is the methodology of this type of research. The influence on the area of contact between the tool and the workpiece caused by geometry of the workpiece and the angles of wrapping was determined.

KEYWORDS: thin-wall elements, CAD systems, cutting layer analysis

Contemporary constructions in the aviation industry are based mainly on thin-walled pocket elements with complex geometry (fig. 1). The machining of such elements is difficult due to the occurrence of elastic and plastic deformations of the structure. In the case of machining the corners of the outer and inner pockets of these elements, the angle of wrap of the tool with the material to be machined can be significantly changed. It is recommended, therefore, that the processing of the corners should follow the appropriate strategy, which should reduce the cutting forces and deformation of the workpiece walls $[4,5,7]$.

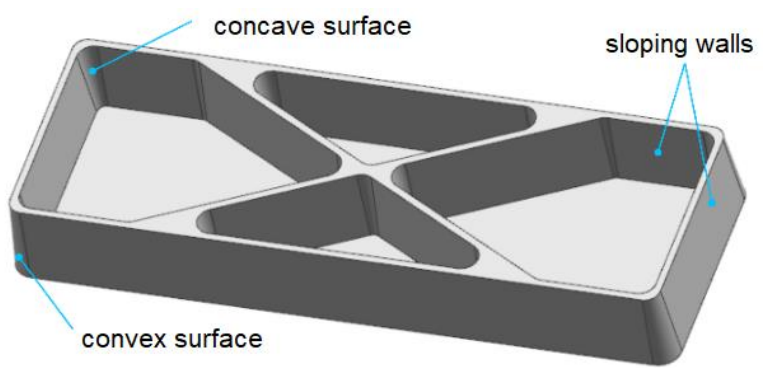

Fig. 1. Example of a thin-walled element with a complex geometry

The most commonly used type of complex surface treatment is point milling, and in the case of rectangular areas, circumferential milling is more efficient [2].

\footnotetext{
* Dr hab. inż. Jan Burek prof. PRz (jburek@prz.edu.pl), mgr inż. Rafał Flejszar (r.flejszar@prz.edu.pl) - Katedra Technik Wytwarzania i Automatyzacji, Wydział Budowy Maszyn i Lotnictwa Politechniki Rzeszowskiej
}

Due to the low stiffness of thin-walled elements, the deformation of their walls is a serious problem. The deformation of the walls and the associated geometric imperfections of the work surfaces are influenced not only by the geometry of the workpiece. The technological and geometric parameters of the cutting layer, which directly affect the cutting forces, are also of great importance. Therefore, the computer simulation of possible cutting forces $[3,6,8]$ is used already at the design stage of machining.

Analytical models allow for fast prediction of not only cutting forces, but also deformations, using relatively low computing power. Their main advantage is the ability to estimate the cutting forces already at the design stage of the technological process, without the need to reach advanced systems using the finite element method.

The basic requirement of this method is the knowledge of the geometrical model of the cutting layer. In three-axis milling, such a model is known and widely used, however, it is very difficult to analytically determine the geometrical parameters of the cutting layer for five-axis machining. A more effective method is the analysis of the tool contact with the machined surface using the CAD system (Fig. 2) [1, 2, $6]$.

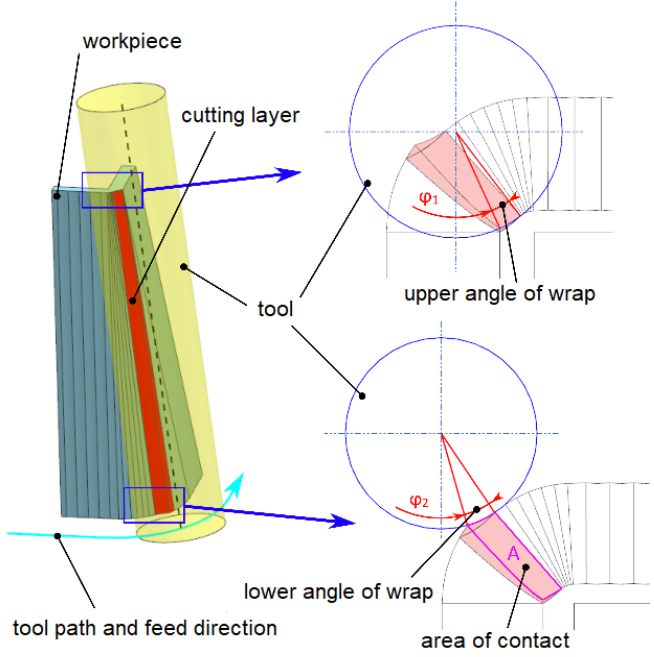

Fig. 2. Simulation analysis of the cutting layer 
The purpose of the work was to simulate the shaping of a machined layer in a circumferential machining with a cylindrical milling cutter for a rectangular surface and to determine the influence of workpiece geometry on the geometrical parameters of the machined layer.

\section{Simulation tests}

Parametrized three-dimensional test models of thinwalled elements of rectangular convex and concave surfaces, semi-finished models and a cylindrical cutter model were made (fig. 3 ).
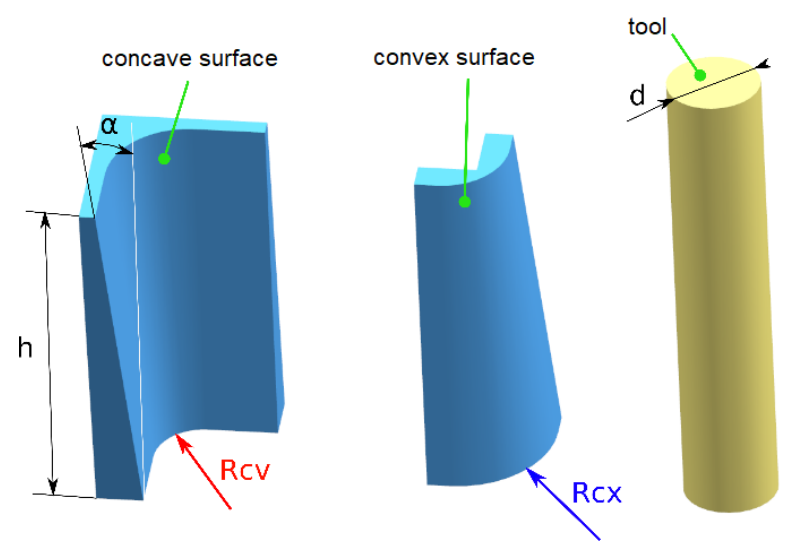

Fig. 3. Models accepted for simulation tests

Simplification of cutter geometry as a cylinder (no inclination of the cutting edge), constant milling diameter $d=$ $8 \mathrm{~mm}$, angle of inclination of the workpiece $\alpha=5^{\circ}$, wall height $h=30 \mathrm{~mm}$, cutting depth $a_{p}=30 \mathrm{~mm}$ and cutting width $a_{\mathrm{e}}=0.5 \mathrm{~mm}$. The only variables were: radii of rounding the concave surface $R_{\mathrm{cv}}$ and convex $R_{\mathrm{cx}}$, which were technologically and geometrically limited by the diameter of the milling cutter, the angle and height of the walls of the workpiece.

Schema of the cutter with the machined surface is shown in fig. 4.

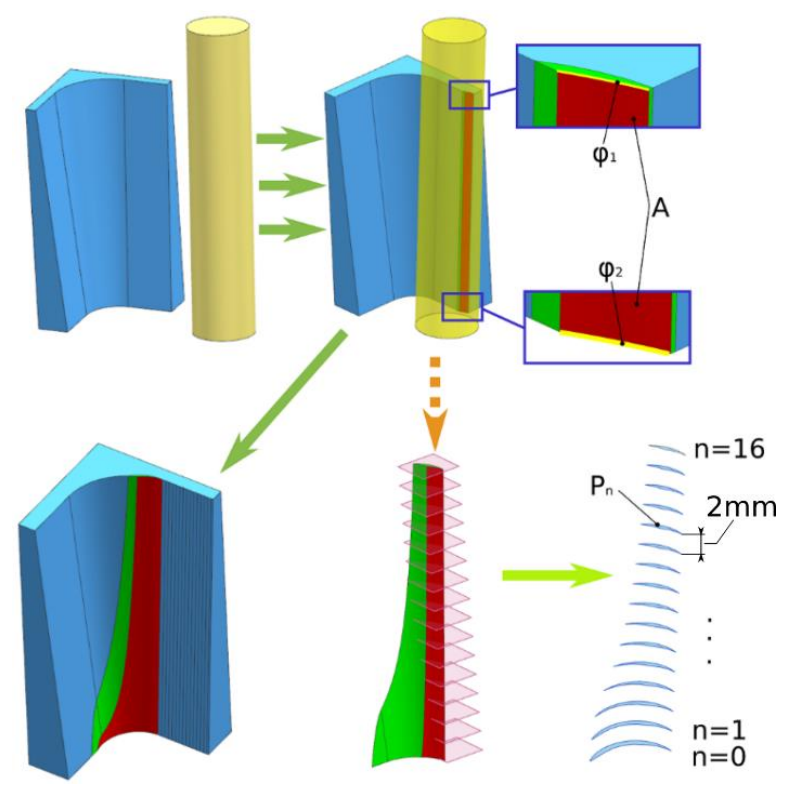

Fig. 4. Milling cutter schema: $\varphi_{1}$ - lower wrap angle, $\varphi_{2}$ - upper wrap angle, $A$ - cutter's contact surface area with workpiece, $P_{\mathrm{n}}$ - cutter section cross-section area
The first step was to determine the position of the cutter relative to the workpiece. The next step was to transform the tool model according to the direction of the trajectory (determined by the geometry of the workpiece) by the feed value $\left(f_{n}=0.4 \mathrm{~mm} / \mathrm{rev}\right)$. Next, a joint part of the workpiece and tool was created, based on which it was possible to measure the area of contact $A$, the wrap angles $\varphi$ and the cut area of the cutting layer $P_{\mathrm{n}}$ for any tool position (where $n$ denotes the height $h$ with a step of $2 \mathrm{~mm}$ ). Then the common part was subtracted from the blank body. This algorithm was repeated until the finished surface was obtained $[1,2]$.

\section{Results}

The simulation allowed for plotting angles of wrapping and the area of contact of the tool with the surface to be machined, depending on the path traveled by the tool (Fig. $5)$.

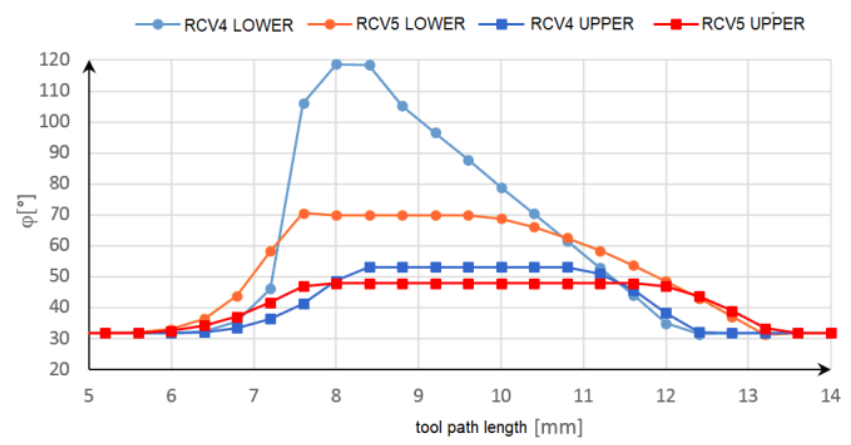

Fig. 5. Wrap angles for a concave surface

For the concave surface, using the parameter $R_{\mathrm{cv}}=4$ $\mathrm{mm}$ (equal to the tool radius) a very large increase in the wrap angle is visible.

The lower wrap angle changes to a much greater extent than the upper wrap angle. Changing the angles of the belt leads to an increase in the area of contact between the tool and the workpiece (fig. 6).

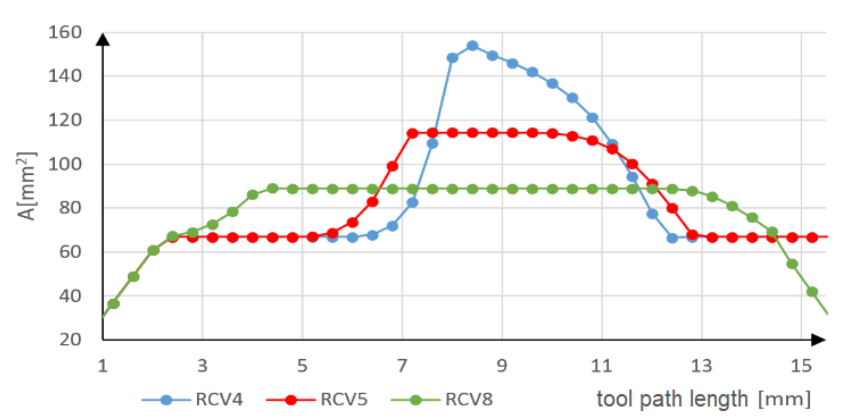

Fig. 6. Contact surface for a concave surface

With the increase of the radius of the concave rounding, a significant decrease of the wrap angles and the contact surface area is visible. With $R_{\mathrm{cv}}$ rounding $=5 \mathrm{~mm}$, the measured value drops by almost $25 \%$. A very rapid increase in the value of the wrap angle and the contact surface is visible when the tool enters the concave fillet region. This causes a large step change in the cross-sectional area of the cutting layer in relation to the nominal value when processing a flat surface (fig. 7). 


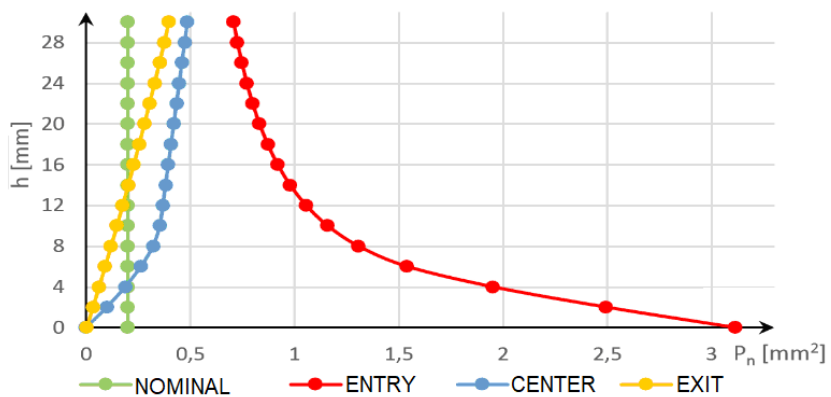

Fig. 7. Cross-sectional area of the cutting layer for the machining of concave rounding for geometry with $R_{\mathrm{CV}}=4 \mathrm{~mm}$

When entering the concave fillet region, a very large change in the cross-sectional area takes place in the lower cross-sections of the cutting layer, after which it decreases almost to zero. This means that when the concave rounding is performed, the tool, in spite of the large lower belt angle, does not actually cut any excess material with its lower part.

In the case of a convex surface for very small radius values, the area of contact and the angles of wrapping considerably decrease (fig. 8, fig. 9).

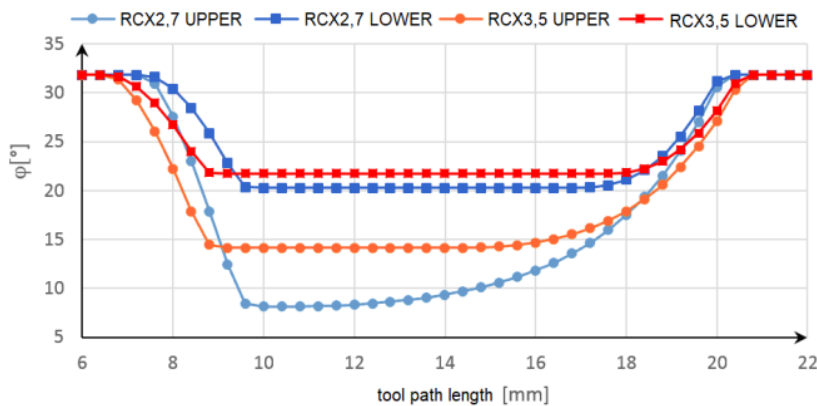

Fig. 8. Wrap angles for convex surfaces

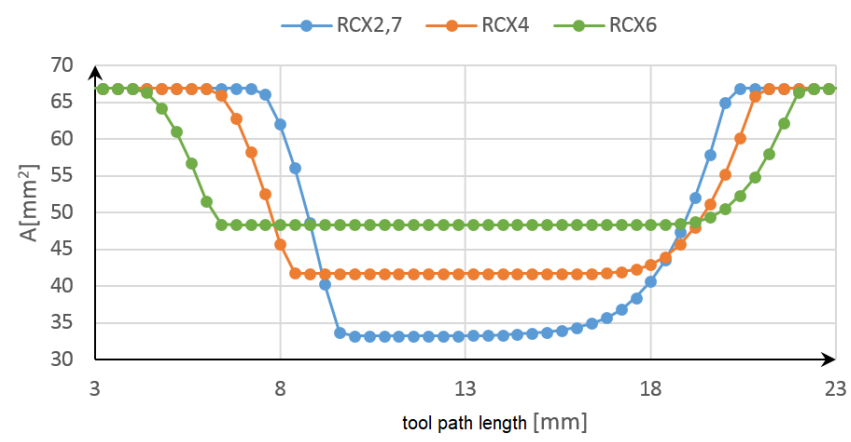

Fig. 9. Contact surface for a convex surface

For this type of corners, larger changes are observed for the upper angle of wrap. This is related to the geometry of the model (the direction of wall inclination).

\section{Analysis of results}

Based on the results of the simulation, experimental areas of the tool contact surface were determined depending on the radius of rounding and the angles of wrap:

$$
\begin{gathered}
A_{C V}=\left(1,34 \varphi_{1}^{2}+8,13 \varphi_{2}^{2}+R_{C V}\left(0,208 \varphi_{1}+1,02 \varphi_{2}\right)+\right. \\
\left.+1,1 \varphi_{1} \varphi_{2}\right) 10^{-2}+38,32 \\
A_{C X}=\left(0,741 \varphi_{1}^{2}+0,254 \varphi_{2}^{2}+R_{C X}\left(1,17 \varphi_{1}+0,155 \varphi_{2}\right)+\right. \\
\left.+2,89 \varphi_{1} \varphi_{2}\right) 10^{-2}+26,79
\end{gathered}
$$

The extreme values of area of contact and angles of wrap of concave surfaces with the values obtained for the treatment of a flat surface were compared (fig. 10).

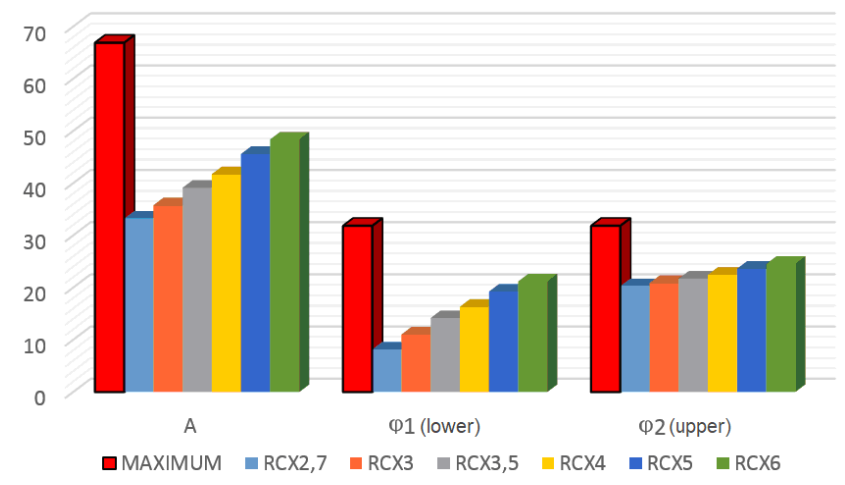

Fig. 10. Measurements of contact surface area, lower and upper wrap angle for concave surfaces

Visible is more than one and a half increase of the contact surface area and over fourfold increase of the wrap angle for corners with radius formed directly by the diameter of the milling cutter $\left(R_{\mathrm{CV}}=4 \mathrm{~mm}\right)$. However, already with geometry with a radius greater by $1 \mathrm{~mm}$, the contact surface area is reduced by $25 \%$ and the angle of wrap around the base of the milling cutter by $40 \%$. In the case of the upper angle of wrap, the effect of changing the radius by $1 \mathrm{~mm}$ reduced the angle values by less than $10 \%$.

For convex surfaces, the opposite effect can be seen (fig. 11).

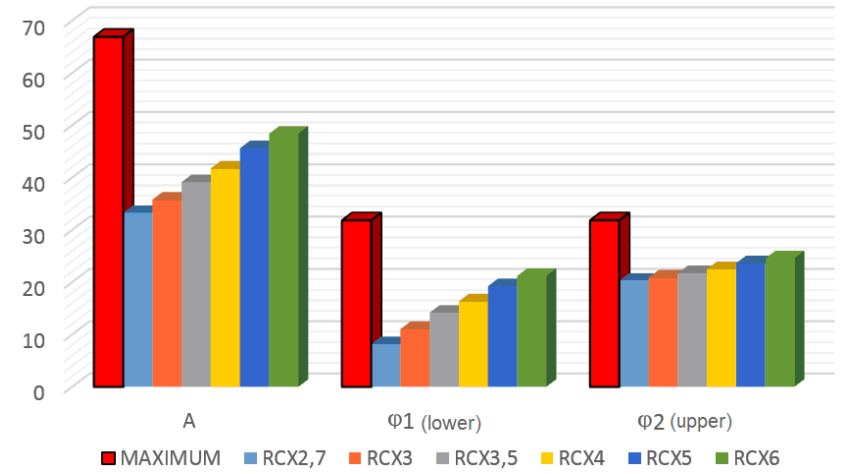

Fig. 11. Measurements of contact surface area, lower and upper wrap angle for convex surfaces

In the case of an almost sharp corner $\left(R_{\mathrm{cx}}=2.7 \mathrm{~mm}\right)$, the value of the contact surface area decreases by approx. $50 \%$ and the value of the upper wrap angle by approx. $75 \%$ compared to the processing a flat wall. When forming a convex surface with a radius of curvature not exceeding the diameter of the milling cutter, the geometrical parameters of the cutting layer are significantly reduced.

\section{Conclusions}

The geometry of the model has a significant impact on the geometrical parameters of the cutting layer. Already a slight modification of it can cause very large changes both in the area of contact and angles of the tool. A very large change in the cross-sectional area of the cutting layer confirms the previously applied feed reduction, especially at the entrances to the concave corners. It is possible to increase the cutting efficiency of convex corners by changing the positioning method or increasing the feed. 
The presented method of cutting layer analysis using a CAD system, after implementing a mathematical model, may be the basis for analytical determination of cutting forces. They can be input data in the tool path optimization process, in order to minimize the probability of geometric errors and performance maximization, already used at the design stage of the technological process.

\section{REFERENCES}

1. Boz Y., Erdim H., Lazoglu I. "A comparison of solid model and three-orthogonal dexelfield methods for cutter-workpiece engagement calculations in three- and five-axis virtual milling". International Journal of Advanced Manufacturing Technology. 81, 5-8 (2015): pp. 811-823.

2. Burek J., Żurawski K., Żurek P., Sałata M. „Badania symulacyjne strefy styku w pięcioosiowej obróbce powierzchni prostokreślnych frezem stożkowym". Mechanik. 8-9 (2017): pp. 718-720.

3. Campatelli G., Scippa A. "Prediction of milling cutting force coefficients for Aluminum 6082-T4". Fifth CIRP Conference on High Performance Cutting. 1 (2012): pp. 563-568.

4. Kuczmaszewski J., Pieśko P., Zagórski I., Włodarczyk M. "Obróbka elementów cienkościennych wykonanych ze stopów aluminium i magnezu". Lublin: Politechnika Lubelska, 2015.

5. Kuczmaszewski J., Pieśko P., Doluk E. „Obróbka naroży wewnętrznych o małym promieniu zaokrąglenia". Mechanik. 5-6 (2017): pp. 418-420.

6. Qu S., Zhao J.B., Wang T.R. "Experimental study and machining parameter optimization in milling thin-walled plates based on NSGA-II". International Journal of Advanced Manufacturing Technology. 89, 5-8 (2017): pp. 2399-2409.

7. Tang A.J., Liu Z.Q. "Deformations of thin-walled plate due to static end milling force". Journal of Materials Processing Technology. 206, 1-3 (2008): pp. 345-351.

8. Wu B.H., Yan X., Luo M., Gao G. "Cutting force prediction for circular end milling process". Chinese Journal of Aeronautics. 26 4 (2013): pp. 1057-1063.

Translation of scientific articles, their computer composition and publishing them on the website www.mechanik.media.pl by original articles in Polish is a task financed from the funds of the Ministry of Science and Higher Education designated for dissemination of science.

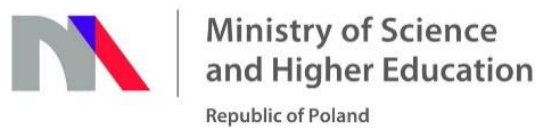

